\section{ANC moves on science policy}

\section{Johannesburg}

ThE African National Congress (ANC) held its first conference on science and technology here two weeks ago, at the University of the Witwatersrand. Described by Mohammed Valli Moosa, head of the ANC's political committee, as "successful far beyond expectations", the conference was meant to discuss the development of a national science and technology policy with as wide a crosssection of opinion as possible

A year ago, few people in South Africa would have foreseen the presidents of the Council for Scientific and Industrial Research (Brian Clark), the Foundation for Research Development (Rein Arndt) and Atomic Energy Corporation chief Waldo Stumpf, discussing science and technology policy with Valli Moosa and Max Sisulu (head of the ANC's economic policy department). Other delegates included representatives from the Electricity Supply Commission (ESCOM), the universities and the private sector.

But even more remarkable was the degree of consensus. Valli Moosa outlined the ANC's draft position paper on science and technology policy (prepared by its interim science and technology group) in his opening address, but emphasized that it was mainly intended as a framework for discussion.

One of Moosa's prominent themes was the need to transform technology policy from its past emphasis on defence and the oil-from-coal industry to applications required for an improvement of living standards of South Africans or directed towards goods that could be produced competitively for international markets. The ANC, he said, is "acutely mindful that economic growth is to a great measure driven by advances in technology.'

The ANC regards electrification as a technological priority, because of health problems arising from wood-smoke pollution in the townships, the expectation that electric light would enable people to study at night and the ecologically disastrous consequences of woodcollection. Yet the problems associated with electrification of the townships are not technological, but financial. This task would require an estimated $\mathrm{R} 6,000$ million, but no increased electricity generation, as ESCOM's existing power stations have a surplus capacity of 30 per cent.

A more intractable problem is the $\mathrm{SO}_{2}$ emission in the Eastern Transvaal Highveld, where 80 per cent of South Africa's electricity is produced. Deposition amounts to $30-40$ tonnes per square kilometre, matching the worst conditions found in Europe, but the cost of fitting scrubbers to each of thirty-two coal-fired power stations would increase the cost of electricity by up to 50 per cent, making it even less affordable to the poor.

There was also concern at the conference about the declining proportion of South Africa's gross domestic product (GDP) spent on research and development (see Nature 344, 185; 1990). The conference urged a commitment to spending a certain percentage of GDP on research and development. David Jacobson of Altron, the South Africa's largest electronics corporation, made an appeal for tax incentives for research and development spending by the private sector. Theoretical physicist Rob Adam, of the ANC interim science and techology group, assured delegates that the ANC did not advocate "killing" fundamental research, as it recognized its importance.

The shortage of scientific and technical manpower in South Africa, and its racial composition, also occupied the conference. Ninety-six per cent of the engineers and 89 per cent of scientists in South Africa are white, largely as a consequence of an education system that produces one mathematics and science matriculation exemption for every 10,000 black school entrants

While there are (badly paid) jobs aplenty for science graduates in primary and secondary schools, some debate centred around the extent to which a shortage of technical expertise is currently limiting industrial growth. One biack South African who had recently returned to the country with a PhD in biochemistry from the University of California at Santa Cruz complained that he was unable to find a job in the private sector.

Professor C. C. Mjojo, president of the Network of African Scientific Organisations, in a closing address, explained how the network is attempting to convince African heads of state of the importance of science and technology in the development of the continent. It has already persuaded President Daniel Arap Moi of Kenya to convene a summit of 16 leaders to focus attention on the issue. Mjojo added that his organization was awaiting a signal from the ANC to begin talking to South African scientists. Valli Moosa responded that the ANC's isolationist policy had been directed at the "apartheid regime", and that Mjojo's presence showed that interaction had already begun.

Meanwhile, last week, Nelson Mandela received honorary degrees from both the University of the Western Cape and the University of Cape Town. Ironically, the graduation ceremony at UCT, held on the university's rugby field to accommodate all the guests, was presided over by the statue of Cecil John Rhodes gazing towards the hinterland.

\section{Monkey case in Supreme Court}

\section{Washington}

IN a surprising twist to the long-running and tortuous court battle over the 'Silver Spring monkeys' - the cause célèbre of the US animal-rights movement - the US Supreme Court agreed last week to hear arguments on a key procedural issue in the case, a move that could open yet another bloody chapter in the history of the research primates.

Since the monkeys first surfaced in 1981 as the focus of an undercover investigation by Alex Pacheco, who later went on to co-found People for the Ethical Treatment of Animals (PETA), animal-rights activists have maintained an unrelenting legal war on their behalf.

But until the Supreme Court decided to hear the case, it seemed that the activists were nearing the end of their legal tether. A suit, filed in Louisiana state court, charging the National Institutes of Health (NIH) with improper handling of the case, was referred last year to federal court, where it was dismissed. The activists asked the Supreme Court to rule on the propriety of that transfer, but had little hope that the court would take the case. But last week's decision raises the possibility of yet another round of legal battling, perhaps the fiercest yet. If the court sides with PETA, the case will go back to state court, where, for the first time, a judge will review the claims against the $\mathrm{NIH}$, rather than simply procedural issues.

Christopher Anderson

\section{ASTRONOMY}

\section{No end of blame}

\section{Washington}

TeCHnicians working on the Hubble Space Telescope (HST) knew that something was wrong with the shaping of the main mirror, but did not tell their supervisors, a NASA investigative team revealed last week. On at least three occasions, tests showed clear signs of a spherical aberration in the mirror, but the results were blamed on faulty test instruments and senior management was kept in the dark, said Lew Allen, former NASA administrator and chairman of the investigative panel.

The main error arose when a small fleck of anti-reflective paint chipped off a highly sensitive optical metering device, leading to a false reflection during tests. Other instruments recorded the error, but because they were less sensitive, it was discounted, Allen said. The technicians knew that the mirror was not being built as designed, but "the fact that there were errors did not reach anyone outside of the fabrication division". The cost of correcting the fault is estimated to be $\$ 40-50$ million. Christopher Anderson 